\title{
SYSTEMIC REVIEW OF MANAGEMENT OF KNEE OSTEOCHONDRITIS DISSECANS BY MOSAICPLASTY
}

(REVIEW ARTICLE)

By

\author{
Hassan Mohamed Hassan, Mohamed M. Besar and Emad M. Zayed \\ Department of Orthopedic Surgery, Faculty of Medicine, Al-Azhar University, Egypt \\ E-mail: dr.hassan90@hotmail.com
}

\begin{abstract}
Background: Osteochondritis dissecans (OCD) is a pathological process affecting the subchondral bone of the knee in children and adolescents with open growth plates (juvenile OCD) and young adults with closed growth plates (adult OCD). It may lead to secondary effects on joint cartilage, such as pain, edema, possible formation of free bodies and mechanical symptoms, including joint locking.
\end{abstract}

Objective: To detect the osteochondral auto graft Transplantation in Management of OCD Knee as regards clinical outcomes and complications.

Subjects and methods: This systematic review include 14 original articles published from January 2014 to June 2019 which was that 14 studies were included prospective studies were the commonest type appeared in 6 studies followed by Case series in 4 studies, retrospective in 3 studies and Randomized controlled trial in one study.

Results: Results of the study revealed that the commonest score used to assess outcome was: Knee Injury and Osteoarthritis Outcome Score (KOOS) which used in 5 studies and shows improvement after treatment, International Knee Documentation Committee (IKDC) scores appeared in 4 studies preoperative and postoperative values shows significant increase postoperative, Hospital for Special Surgery (HSS) appeared in one study, and results revealed that 54 cases showed complications, graft failure founded among 16 cases and 34 needs reoperations.

Conclusion: On the basis of the good clinical and MRA results obtained at long-term follow-up, mosaicplasty can be considered a safe and reliable option for the treatment of unstable OCD in adult patients.

Keywords: Complications, IKDC scores, Osteochondritis dissecans, Systematic Review, Treatment.

\section{INTRODUCTION}

Articular cartilage defects are incapable of self-repair. They are acquired defects, often from trauma or osteochondritis dissecans (OCD. Patients can be fit, active and have a high functional demand and high xpectations. If untreated, lesions of articular cartilage can progress to osteoarthritis of the joint.
The underlying subchondral bone support plays a role in the stability and outcome of any repair. A number of different surgical techniques have been described for the treatment of these lesions. These techniques include micro fracture, autologous osteochondral cylinder transplantation (mosaicplasty), artificial bone graft substitutes and cell-based repair techniques such as autologous 
chondrocyte implantation (ACI) (Hindle et al., 2013).

The present study aimed to detect osteochondral autograft transplantation in management of OCD knee as regards clinical outcomes and complications.

\section{PATIENTS AND METHODS}

The following information/data were extracted from studies that met the inclusion criteria: name of the first author, year of publication, study design, number of participants in each treatment group, participants' age and gender, type of intervention in Osteochondral Auto graft Transplantation in management of OCD knee. Search terms used were suspensory mechanism Osteochondral Auto graft Transplantation techniques

The electronic databases up to June 2019 of 'Pub med Medline', 'EMbase', and 'Google Scholar' were explored using the combination of the following searchterms:

\section{Inclusion criteria:}

English-language original articles published from January 2014 to June 2019, Adults older than 18 years old and All RCTs , clinical trials, case control , case report or cohort study of the subjective and objective outcomes, and complications of Mosaicplasty.

\section{Exclusion criteria:}

Patients with lesions less than $3 \mathrm{~cm}$, patients treated conservatively, metaanalyses or nonhuman studies, those where it is impossible to tell from the abstract or title that they meet the described inclusion criteria, or patient underwent surgical interventions before in the knee.

\section{Statistical Analysis:}

A primary search of databases yielded 420 records. After duplicates removal, 328 potentially eligible articles were identified. A total of 14 studies fulfilled the inclusion criteria, and were included in the final systematic review.

\section{RESULTS}

Total number of patients was 328, Mean age of the included patients was 32 years, Median was 31.85 years, Minimum - Maximum 21.2-40.8, and (228 69.5\%) of included cases were females (Table 1).

Mean defect size was 4.2 (cm2), Median was 3.8, Minimum- Maximum 36.1 (Table 2).

The commonest score used to assess outcome was KOOS which used in 5 studies and shows improvement after treatment, IKDC scores appeared in 4 studies preoperative and postoperative values shows significant increase postoperative, HSS appeared in one study (Table 3).

54 cases showed complications graft failure founded among 16 cases and 34 needs reoperations (Table 4). 
SYSTEMIC REVIEW OF MANAGEMENT OF KNEE...

Table (1): Characteristics of the included studies

\begin{tabular}{|c|c|c|}
\hline Study & Year & Age (y) \\
\hline Quarch et al., 2014 & 2014 & NR \\
\hline Astur et al., 2014 & 2014 & 37.6 \\
\hline Ulstein et al., 2014 & 2014 & 32.7 \\
\hline Zak et al., 2014 & 2014 & 38 \\
\hline Aldrian et al., 2014 & 2014 & 33.3 \\
\hline Hindle et al., 2014 & 2014 & 35.8 \\
\hline Filardo et al., 2014 & 2014 & 30.2 \\
\hline Miller et al., 2015 & 2015 & ND \\
\hline Ronga et al., 2015 & 2015 & 21.2 \\
\hline Clavé et al., 2016 & 2016 & 28.3 \\
\hline Erol et al., 2016 & 2016 & 40.8 \\
\hline Zellner et al., 2017 & 2017 & 29 \\
\hline Solheim et al., 2017 & 2017 & 31 \\
\hline Carey et al., 2019 & 2019 & 26.1 \\
\hline
\end{tabular}

Table (2): Defect size

\begin{tabular}{|c|c|c|}
\hline Study & Year & Defect size $\left(\mathbf{c m}^{\mathbf{2}}\right)$ \\
\hline Quarch et al., 2014 & 2014 & 4.6 \\
\hline Astur et al., 2014 & 2014 & NR \\
\hline Ulstein et al., 2014 & 2014 & 3 \\
\hline Zak et al., 2014 & 2014 & 5.8 \\
\hline Aldrian et al., 2014 & 2014 & 3.8 \\
\hline Hindle et al., 2014 & 2014 & 4.5 \\
\hline Filardo et al., 2014 & 2014 & 3 \\
\hline Miller et al., 2014 & 2015 & 3 \\
\hline Ronga et al., 2015 & 2015 & 3.8 \\
\hline Clavé et al., 2016 & 2016 & 4.07 \\
\hline Erol et al., 2016 & 2016 & 3.7 \\
\hline Zellner et al., 2017 & 2017 & 6.1 \\
\hline Solheim et al., 2017 & 2017 & 3.4 \\
\hline Carey et al., 2019 & 2019 & 6 \\
\hline
\end{tabular}


HASSAN MOHAMED HASSAN et al.,

Table (3): Outcome assessments score used

\begin{tabular}{|c|c|c|c|c|c|c|c|c|c|}
\hline Parmeters & $\begin{array}{c}\text { HSS } \\
\text { pre }\end{array}$ & $\begin{array}{l}\text { HSS } \\
\text { post }\end{array}$ & $\begin{array}{c}\text { IKDC } \\
\text { score } \\
\text { pre } \\
\end{array}$ & $\begin{array}{c}\text { IKDC } \\
\text { score } \\
\text { post } \\
\end{array}$ & $\begin{array}{c}\text { KOOS } \\
\text { Pain }\end{array}$ & $\begin{array}{c}\text { KOOS } \\
\text { Symptoms }\end{array}$ & $\begin{array}{c}\text { KOOS } \\
\text { ADL }\end{array}$ & $\begin{array}{c}\text { KOOS } \\
\text { Sport/ } \\
\text { Rec } \\
\end{array}$ & $\begin{array}{c}\text { KOOS } \\
\text { QoL }\end{array}$ \\
\hline $\begin{array}{c}\text { Quarch et } \\
\text { al., 2014 }\end{array}$ & ND & ND & ND & ND & ND & ND & ND & ND & ND \\
\hline $\begin{array}{c}\text { Astur et al., } \\
2014\end{array}$ & ND & ND & ND & ND & ND & ND & ND & ND & ND \\
\hline $\begin{array}{c}\text { Ulstein et } \\
\text { al., 2014 } \\
\end{array}$ & ND & ND & ND & ND & $\Delta 11.8$ & $\Delta 8.5$ & $\Delta 7.5$ & $\Delta 41.3$ & $\Delta 25$ \\
\hline $\begin{array}{c}\text { Zak et al., } \\
2014\end{array}$ & ND & ND & ND & ND & $\Delta 19.5$ & $\Delta 3.6$ & $\Delta 16.5$ & $\Delta 20$ & $\Delta 18.7$ \\
\hline $\begin{array}{l}\text { Aldrian et } \\
\text { al., 2014 }\end{array}$ & ND & ND & 44.1 & 59 & 69 & 50 & 75 & 39 & 51 \\
\hline $\begin{array}{c}\text { Hindle et } \\
\text { al., 2014 }\end{array}$ & ND & ND & ND & ND & 77 & 60 & 81 & 40 & 43 \\
\hline $\begin{array}{c}\text { Filardo et } \\
\text { al., 2014 }\end{array}$ & ND & ND & 34.5 & 66.3 & ND & ND & ND & ND & ND \\
\hline $\begin{array}{c}\text { Miller et al., } \\
2015\end{array}$ & ND & 9.46 & ND & ND & ND & ND & ND & ND & ND \\
\hline $\begin{array}{c}\text { Ronga et al., } \\
2015 \\
\end{array}$ & ND & ND & ND & ND & ND & ND & ND & ND & ND \\
\hline $\begin{array}{c}\text { Clavé et al., } \\
2016\end{array}$ & ND & ND & 39.6 & 78.9 & ND & ND & ND & ND & ND \\
\hline $\begin{array}{c}\text { Erol et al., } \\
2016\end{array}$ & ND & ND & ND & 70.2 & ND & ND & ND & ND & ND \\
\hline $\begin{array}{l}\text { Zellner et } \\
\text { al., } 2017\end{array}$ & ND & ND & 42.6 & 79.7 & ND & ND & ND & ND & ND \\
\hline $\begin{array}{c}\text { Solheim et } \\
\text { al., 2017 }\end{array}$ & ND & ND & ND & ND & ND & ND & ND & ND & ND \\
\hline $\begin{array}{c}\text { Carey et al., } \\
2019\end{array}$ & ND & ND & ND & ND & 79.3 & 60.2 & 85.5 & 53.9 & 52.7 \\
\hline
\end{tabular}


Table (4): Complications

\begin{tabular}{|c|c|c|c|c|c|c|c|c|c|c|c|c|c|c|}
\hline Parameters & 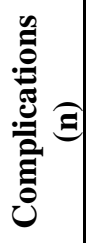 & 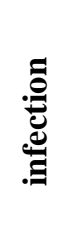 & 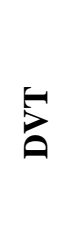 & 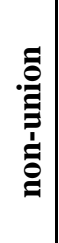 & 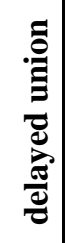 & 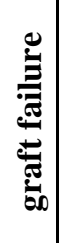 & $\begin{array}{l}\frac{\pi}{\tilde{E}} \\
\frac{\bar{E}}{\mathrm{E}}\end{array}$ & 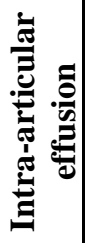 & 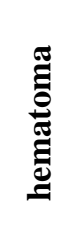 & 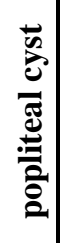 & 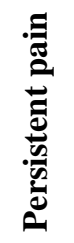 & 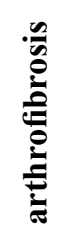 & 参 & 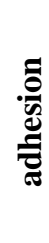 \\
\hline $\begin{array}{c}\text { Quarch et al., } \\
2014\end{array}$ & 1 & 0 & 0 & 0 & 0 & 0 & 1 & 0 & 0 & 0 & 0 & 0 & 0 & 0 \\
\hline $\begin{array}{c}\text { Astur et al., } \\
2014\end{array}$ & 3 & 0 & 0 & 0 & 0 & 0 & 0 & 0 & 0 & 0 & 0 & 3 & 0 & 0 \\
\hline $\begin{array}{c}\text { Ulstein et al., } \\
2014\end{array}$ & 4 & 0 & 0 & 0 & 0 & 0 & 0 & 0 & 0 & 0 & 0 & 0 & 5 & 0 \\
\hline $\begin{array}{c}\text { Zak et al., } \\
2014\end{array}$ & 0 & 0 & 0 & 0 & 0 & 0 & 0 & 0 & 0 & 0 & 0 & 0 & 0 & 0 \\
\hline $\begin{array}{c}\text { Aldrian et al., } \\
2014\end{array}$ & 3 & 0 & 0 & 0 & 0 & 0 & 0 & 0 & 0 & 0 & 0 & 0 & 0 & 3 \\
\hline $\begin{array}{c}\text { Hindle et al., } \\
2014\end{array}$ & 7 & 1 & 0 & 0 & 0 & 0 & 0 & 0 & 1 & 0 & 6 & 0 & 6 & 0 \\
\hline $\begin{array}{c}\text { Filardo et al., } \\
2014 \\
\end{array}$ & 4 & 0 & 0 & 0 & 0 & 4 & 0 & 0 & 0 & 0 & 0 & 0 & 0 & 0 \\
\hline $\begin{array}{c}\text { Miller et al., } \\
2015 \\
\end{array}$ & 8 & 0 & 0 & 0 & 0 & 8 & 0 & 0 & 0 & 0 & 0 & 0 & 8 & 0 \\
\hline $\begin{array}{c}\text { Ronga et al., } \\
2015 \\
\end{array}$ & 0 & 0 & 0 & 0 & 0 & 0 & 0 & 0 & 0 & 0 & 0 & 0 & 0 & 0 \\
\hline $\begin{array}{c}\text { Clavé et al., } \\
2016\end{array}$ & 6 & 0 & 0 & 0 & 0 & 0 & 1 & 2 & 1 & 1 & 1 & 0 & 0 & 0 \\
\hline $\begin{array}{c}\text { Erol et al., } \\
2016\end{array}$ & 0 & 0 & 0 & 0 & 0 & 0 & 0 & 0 & 0 & 0 & 0 & 0 & 0 & 0 \\
\hline $\begin{array}{c}\text { Zellner et al., } \\
2017 \\
\end{array}$ & 4 & 0 & 0 & 0 & 4 & 4 & 4 & 2 & 0 & 0 & 0 & 3 & 4 & 0 \\
\hline $\begin{array}{c}\text { Solheim et al., } \\
2017\end{array}$ & 4 & 2 & 1 & 0 & 0 & 0 & 0 & 0 & 0 & 0 & 0 & 0 & 1 & 0 \\
\hline $\begin{array}{c}\text { Carey et al., } \\
2019 \\
\end{array}$ & 10 & 0 & 0 & 0 & 0 & 0 & 0 & 0 & 0 & 0 & 0 & 0 & 10 & 0 \\
\hline
\end{tabular}

\section{DISCUSSION}

OCA transplantation is usually performed as a salvage procedure in cases of failed previous cartilage repair or as a primary cartilage repair technique for large osteochondral lesions on the knee, with good and excellent outcomes (Gracitelli et al., 2015). Osteochondritis dissecans (OCD) is a disorder resulting in focal breakdown of the subchondral bone, with potential disruption of the overlying articular cartilage (Eismann et al., 2014).
We found that the mean age of the included patients was 32 years, Median was 31.85 years, Minimum- Maximum 21.2-40.8, and $69.5 \%$ of included cases were females.

Quarch et al. ( 2014) was conducted on 37 patients by removing the osteochondral cylinders from the dorsal medial femoral condyle of the affected knee joint, the study group's average age was $38.3( \pm 10.9)$ years; in the control group, the average age was $39.7( \pm 10.7)$ years. 
In a systematic review of Andrade et al. (2016) reported that a total of 1726 patients (1472 and 254 patients underwent knee and ankle mosaicplasty, respectively) with a mean age of 33.2 years and 34.8 years old for the knee and ankle joints cohorts, respectively.

In a prospective randomized study of Ulstein et al. (2014), Twenty-five patients [mean age 32.3 years, standard deviation (SD) 7.7] were enrolled in the study between November 2000 and June 2006 to compare long-term functional and radiological outcome following $\mathrm{MF}$ and OAT mosaicplasty for full-thickness chondral lesions of the knee.

In this sense, orthopedic surgeons have pursuit in the past an approach that can allow achieving the hyaline or hyalinelike repair of articular defects (Andrade et al., 2016).

The present study revealed that the mean defect size from the 14 participant studies was $4.2(\mathrm{~cm} 2)$, median was 3.8 , Minimum- Maximum 3- 6.1.

In the study of Zellner et al. (2017); the 46 patients had 47 deep, large osteochondral defects of the knee joint (1 patient with bilateral defects; mean defect size, $6.7 \mathrm{~cm} 2$ ). The origin of the osteochondral defects was osteochondritis dissecans $(n=34)$, osteonecrosis $(n=8)$, or subchondral cysts $(n=5)$. Depending on the depth, all defects were treated by cancellous bone grafting (defect depth 10 $\mathrm{mm} ; \mathrm{n}=16$ ) or bone block augmentation (defect depth $0.10 \mathrm{~mm} ; \mathrm{n}=31$ ) combined with MACT.

Richter et al. (2016) discussed the treatment of osteochondral lesions of the knee, lesions with dimensions $<2 \mathrm{~cm} 2$ and found that the best treated through micro-fracture (first-line option) or OTA.

The latter shows more longevity and durability of results, especially among high functional demand patients, when compared with micro-fractures (Krych et al., 2012).

As regard outcome, in the current reviews; we found that the commonest score used to assess outcome was KOOS which used in 5 studies and showed improvement after treatment, IKDC scores appeared in 4 studies preoperative and postoperative values shows significant increase postoperative, HSS appeared in one study, Tl'rico et al. (2018) reported that Postoperative IKDC pain, function, and total scores differed between patients who were satisfied and not satisfied. All KOOS subscale results differed between those who were satisfied and not satisfied. PRO difference scores (change from presurgery to follow-up) varied between satisfied and not-satisfied patients. The mean changes in IKDC pain, function, and total scores were 23.0, 4.1, and 31.9 for satisfied patients and 20.8, 1.3, and 8.3 for patients who were not satisfied, respectively. The mean changes in KOOS subscale results for satisfied and notsatisfied patients were 22.8 and 7.4 (symptoms), 23.9 and 7.4 (pain), 21.2 and 7.7 (activities of daily living), 35.4 and 10.9 (function in sports and recreation), and 37.7 and 11.0 (quality of life), respectively.

Although good results are being reported in the scientific literature regarding the mosaicplasty procedures, there is still the need to bear in mind the potential donor-site morbidity arising 
from the osteochondral plugs harvesting (Andrade et al., 2016).

As regard complications, the current metanalysis demonstrated that 54 cases showed complications graft failure founded among 16 cases and 34 needs reoperations, Ulstein et al. (2014) reported that 5 cases were reoperated, Hindle et al. (2014) revealed that 6 cases were reoperated, 8 cases in Miller et al. (2015), and 10 cases in Carey et al. (2019).

Reports of filling the donor holes with biocompatible material have been published (Bartha et al. 2013), aiming to reduce the donor-site morbidity after the osteochondral harvesting. Nevertheless, the best approach may be to preserve the weight-bearing areas of the knee joint and harvest the osteochondral plugs from potential morbidity-free, minimal nonweight-bearing areas. In this sense, several alternative donor-site areas for mosaicplasty harvesting have been proposed. While the posterior femoral condyles and the calcaneal tuberosity cartilage were considered as unsuitable donor-site alternatives for osteochondral autografting (Thaunat and Beaufils, 2010 and Calder et al., 2015), the lower weightbearing area of the patellofemoral joint and the upper tibio-fibular joint showed promising results in humans without donor-site morbidity associated (Espregueira-Mendes et al., 2012).

Sepsis was reported in 1 of 142 patients in a case series of Ollat et al. (2011) in which patients had OATM, at 8year follow-up.

Infection was statistically significantly more frequent in the weight-bearing as tolerated group ( 2 of 437 patients) than in the non-weight-bearing groups (0 patients) in the case series of Kosiur and Collins, (2014); which was conducted on 534 patients who had OATM at 32 to 39 month follow-up.

\section{CONCLUSION}

In conclusion, on the basis of the good clinical and MRA results obtained at long-term follow-up, mosaicplasty can be considered a safe and reliable option for the treatment of unstable OCD in adult patients. The biological and mechanical principles of this procedure allow treating these complex lesions in a simple way preserving the OCD fragments.

\section{REFERENCES}

1. Andrade R., Vasta S., Pereira R., Pereira H, Papalia R, Karahan M, Espregueira MJ, Resis LR, and Olivera JM (2016): Knee donor-site morbidity after mosaicplasty - a systematic review. Journal of experimental Orthopaedics, 3(1):31-34.

2. Calder JD, Ballal MS, Deol RS, Pearce CJ, Hamilton P and Lutz M (2015): Histological evaluation of calcaneal tuberosity cartilage--A proposed donor site for osteochondral autologous transplant for talar dome osteochondral lesions. Foot Ankle Surg; 21(3):193-197.

3. Carey, J. L, Wall, E. J, Grimm, N. L, Ganley, T. J., Edmonds, E. W.and Anderson, and A. F (2016): Novel arthroscopic classification of osteochondritis dissecans of the knee: a multicenter reliability study. The American Journal of Sports Medicine, 44(7): 1694-1698.

4. Eismann EA,Pettit JR, Wall JE, and Myer DG (2014): Management Strategies for Osteochondritis Dissecans of the Knee in the Skeletally Immature Athlete; Journal of Orthopaedic \& Sports Physical Therapy, 44(9):665-679.

5. Espregueira MJ, Pereira H, Sevivas N, Varanda P, da Silva MV, Monteiro A, Reis LR , and Olivera J (2012): Osteochondral transplantation using autografts from the upper 
tibio-fibular joint for the treatment of knee cartilage lesions. Knee Surg Sports Traumatol Arthrosc, 20(6):1136-1142.

6. Gracitelli GC, Meric G, Pulido PA, McCauley JC and Bugbee WD (2015): Osteochondral allograft transplantation for knee lesions after failure of cartilage repair surgery Cartilage, 6(2):98-105.

7. Hindle $\mathbf{P}$, Hendry JL, and Keating JF (2014): Autologous osteochondral mosaicplasty or TruFit plugs for cartilage repair. Knee Surg Sports Traumatol Arthrosc, 22(6):1235-40.

8. Kosiur JR and Collins RA (2014): Weightbearing compared with nonweight-bearing following osteochondral autograft transfer for small defects in weight-bearing areas in the femoral articular cartilage of the knee. The Journal of Bone and Joint Surgery( American), 96(16):e136-139.

9. Krych AJ, Harnly HW, Rodeo SA and Williams RJ III (2012): Activity levels are higher after osteochondral autograft transfer mosaicplasty than after microfracture for articular cartilage defects of the knee: a retrospective comparative study. J Bone Joint Surg Am, 94 (11):971-978.

10. Miller J, MBA, Matthew V. Smith,y Matthew J. Matava, Rick W. and Brophy YZ (2015): Investigation performed at Washington University, St Louis, Missour, Microfracture and Osteochondral Autograft Transplantation Are Cost-effective Treatments for Articular Cartilage Lesions of the Distal Femur, AJSM PreView,43(11):2175-2181.

11. Ollat D, Lebel B and Thaunat M (2011): Mosaic osteochondral transplantations in the knee joint, midterm results of the SFA multicenter study. Orthopaedics \&
Traumatology, and Surgery \& Research (OTSR), 97: S160-6.

12. Quarch VM, Enderle E, Lotz J, and Frosch KH (2014): Fate of large donor site defects in osteochondral transfer procedures in the knee joint with and without TruFit plugs. Arch Orthop Trauma Surg. 134(5):657-666.

13. Richter DL, Schenck RC Jr, Wascher DC,and Treme G (2016): Knee Articular Cartilage Repair and Restoration Techniques: A Review of the Literature. Sports Health, 8(02):153-160.

14. Tı́rico L, Pulido PA, Demange MK, McCauley JC, and Bugbee WD (2018): Is Patient Satisfaction Associated With Clinical Outcomes After Osteochondral Allograft Transplantation in the Knee. The American Journal of Sports Medicine, 1-6.

15. Ulstein S, Årøen A and Røtterud JH (2014): Microfracture technique versus osteochondral autologous transplantation mosaicplasty in patients with articular chondral lesions of the knee: a prospective randomized trial with longterm follow-up. Knee Surg Sports Traumatol Arthrosc, 22, 1207-1215.

16. Zellner J, Grechenig S, Pfeifer CG, Krutsch W, Koch M, Welsch G, Scherl M, Nerlich M, Seitz J, Zeman F and Angele P (2017): Clinical and Radiological Regeneration of Large and Deep Osteochondral Defects of the Knee by Bone Augmentation Combined With Matrix-Guided Autologous Chondrocyte Transplantation; The American Journal of Sports Medicine ,45(13), 2948-2954. 


\section{دراسة منهجية لاستعراض استخدام زرع الرقع العظم فضروفية

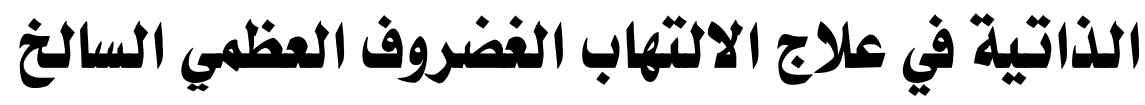 \\ حسن محمد حسن، محمد محمد بيصار، عماد محمد زايا قسم جراحة العظام، كلية طب الأزهر}

E-mail: dr.hassan90@ hotmail.com

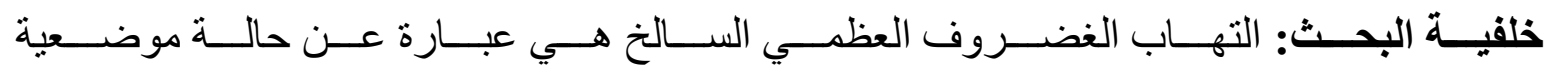

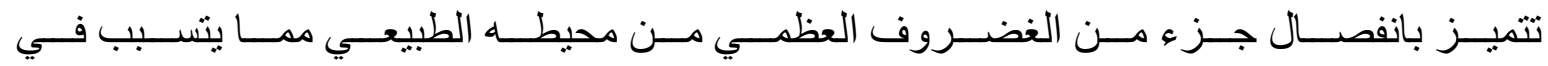

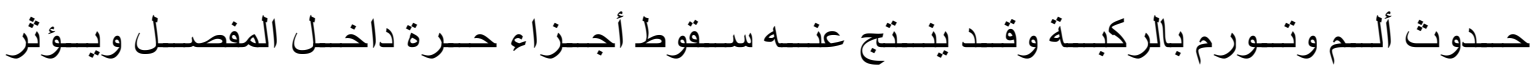

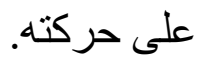

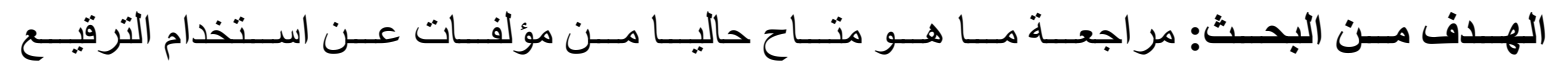

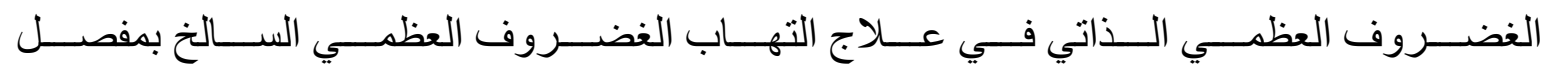

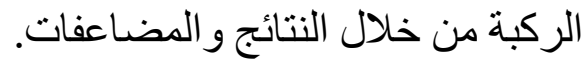

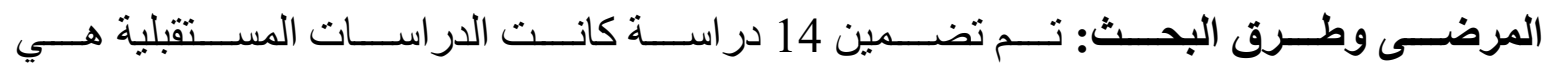

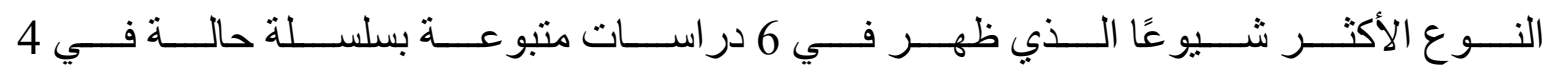

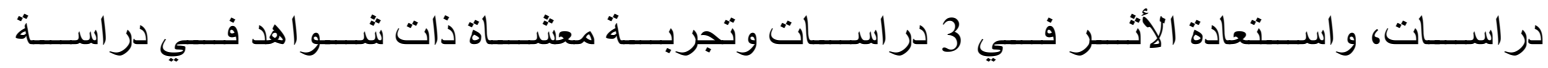
واحدة.

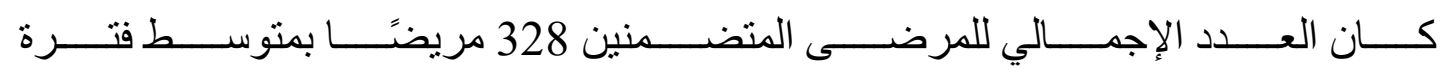

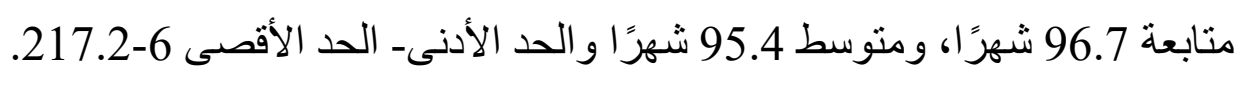

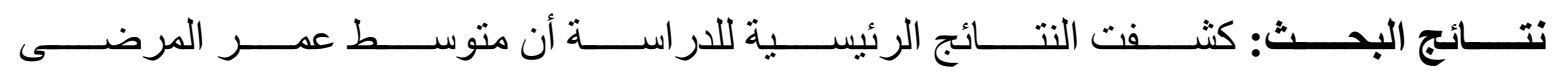

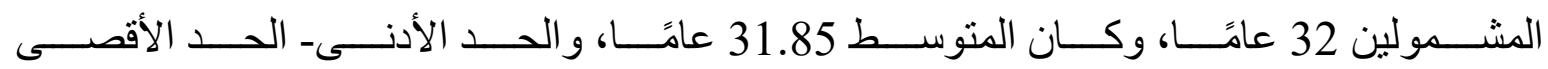
40.8-21.2، و(228 69.5\%) من الحالات المشمولة كانت من الإناث.

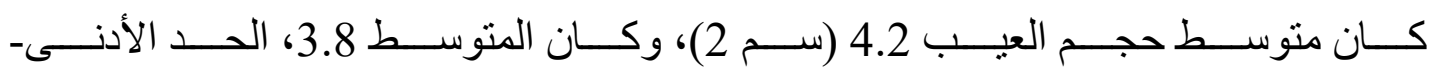

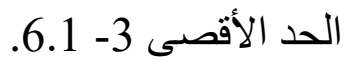




\section{HASSAN MOHAMED HASSAN et al.,}

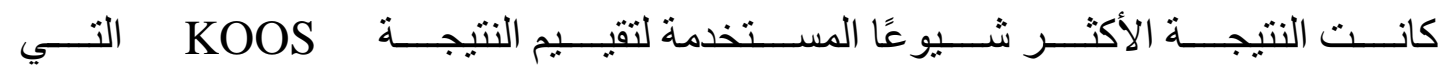

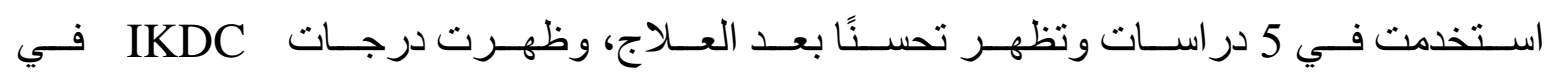

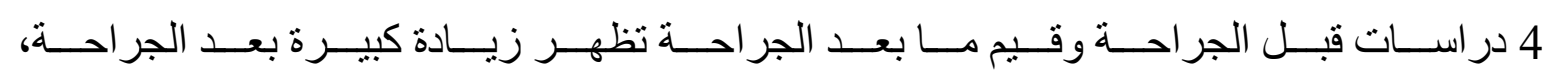

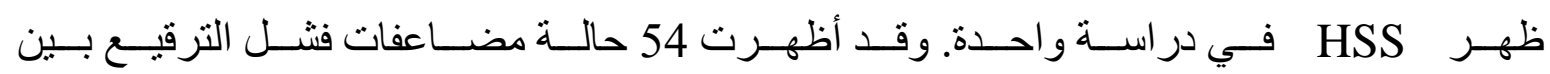
16 حالة و 34 حالة تحتاج إلى إعادة فتح.

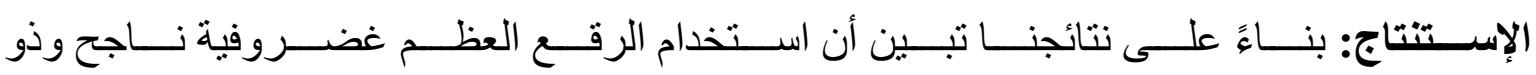

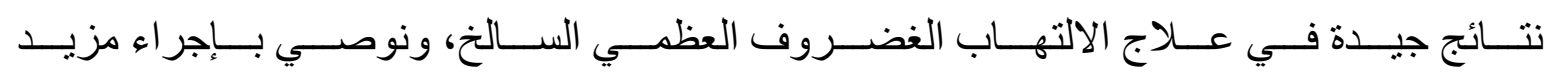
من الدراسات للمرضى الأكبر وفترة متابعة أطول للتأكيد على استتناجنا.

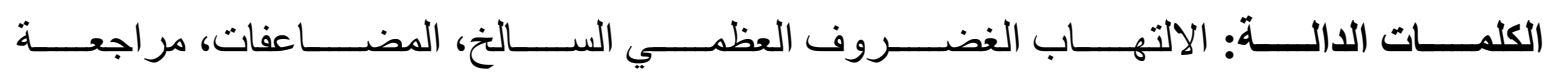
منهجية، العلاج، معدل تقييم IKDC. 